\title{
An analysis of the Value of Chinese Art Songs during the May Fourth Period
}

\author{
Qilong Shi \\ Anshan Normal University \\ Anshan, China
}

\begin{abstract}
In 1919, the "May fourth" new cultural movement came into being. This period coincided with the confrontation between the new and old culture of China. During this period, Chinese modern music culture began to develop gradually, and the musicians represented by Jinhui Li, Yuanren Zhao, Youmei Xiao and $\mathrm{Zi}$ Huang emerged. Their music creation symbolized that the history of Chinese music entered a new historical stage. They combine classical romantic musical expression with Chinese folk music materials to create a large number of representative works of excellent music. These artistic songs reflect the spirit of the "May Fourth movement" and express the requirements of people's pursuit of progress, marking the progress and development of modern Chinese culture, creating a new prospect of Chinese art songs.
\end{abstract} music

Keyword-May Fourth Period; Chinese art songs; style of

\section{INTRODUCTION}

The May 4th Movement is a movement that seeks ideological emancipation. It means the beginning of our new culture movement and has a very important impact on modern and contemporary Chinese ideology and culture. A large number of musicians, represented by Jinhui $\mathrm{Li}$, Yuanren Zhao, Youmei Xiao and Zi Huang, started a new type of music creation. The creation of Chinese art songs in this period created a new dimension in the creation of songs in the history of Chinese music, and made the song creation in our country come into its heyday. Art songs of this period, generally have a meaningful artistic conception, fresh style, fully reflects "the May 4th Movement" spirit, the pursuit of science and the progress of thought of democracy. These art songs of art of high quality, the pursuit of exquisite writing techniques, the integration of Western classical romantic music style and national style China skills, express the lyrics through music, pay attention to national characteristics in music creation, distinctive exquisite ideas and configuration. Giving full play to the role of piano accompaniment in the art songs, make it more image and create a profound artistic conception. According to the characteristics of Chinese tones and rhymes, we can deal with lyrics and tunes, so that music and lyrics can achieve perfect unity in emotion, image and four tones, forming the duet of human voice and piano.It can be said that the new cultural movement of the May Fourth Period has a profound influence on the creation and work of Chinese art songs, and promoted the promotion and dissemination of Chinese art songs. The artistic songs of this period have unique musical style and distinctive features of the times, which have promoted the further development of Chinese art songs.

\section{The Historical VAlue OF ChINESE ART SONGS DURING THE MAY FOURTH PERIOD}

With the "May fourth Movement", the new cultural movement was rising, and the national culture and art were flourishing. During this period, a large number of musicians produced a lot of excellent music works, which had high artistic value and high demand for singing skills. Chinese art songs in this period have a very important historical value in the history of Chinese music, and play a very important role in forming the style of Chinese vocal music, improving the level of Chinese art songs and promoting the development of Chinese vocal music. Its historical value is mainly in the following aspects:

\section{A. It Contributes to the Formation of the Vocal Style}

The art songs of the May Fourth Period played an important role in the history of Chinese national music. The artistic songs which created during this period are deeply marked by a distinctive national style. Learning to sing the May Fourth Period of art songs can help to form the artistic style of Chinese vocal music, which is of great significance for the development of Chinese music. In the May Fourth Period, China's musician has created a lot of background of outstanding works of art songs, such as Jinhui Li, Yuanren Zhao, Youmei Xiao etc. who created "Endorsement song", "Teach me how to forget him", "Ballad" and "Asking" etc. Nowadays, by singing these artistic songs, we can express the national feelings, national styles and national spirit. It has important practical significance for the creation of artistic songs with national characteristics.

\section{B. It Helps to Improve the Level of the Song}

Chinese language has a long history of culture. The art songs created in the May Fourth Period have a high level of use of Chinese language. Through the operation period of the May fourth songs on the singing, can help people learn singing articulation. In the May Fourth Period, art songs created the precedent of Chinese art songs. It combined the language and melody perfectly, laid the foundation for the language structure of Chinese art songs, and pointed out the 
direction for further development and progress. The Chinese art songs created during this period have a distinctive national character. Chinese language consists of the first word of abdominal and suffix. The meaning requires "four" and "Si", according to this characteristics of Chinese language, when performer was singing the art songs in the May Fourth Period, to show Chinese language charm, our pronunciation should be perfect. Through the accurate grasp of the Chinese language of these artistic songs, the artistic standard of Chinese art songs can be further improved.

\section{It is Helpful to the Development of Chinese Vocal Music}

The art songs of the May Fourth Period have typical characteristics of art songs. During this period, the creation of art songs is different from previous song creation. It begins to emphasize the role of melody in songs, not only focuses on lyrics, but also stresses both the lyrics and songs. The creation of songs is between poetry and song, improving the importance of music in the song, through the means of more delicate and accurate music expression. It also emphasis the role of piano accompaniment in the song and its artistic level. The art songs of this period are full of profound insights on life, fate, which is the author of the words .In the " May fourth" period Chinese art songs is milepost Chinese vocal music history, during this period the emergence of a large number of outstanding musicians, they created a new situation Chinese art songs and singing, created a lot of excellent music, In this period the art songs from the melody to harmony, organization skills techniques have reached a very high artistic level. For example "The mighty river flows eastward" "Asking" and "tell me how to forget him" have a rigorous skill and strong singing, is still loved by the people. These artistic songs have greatly enriched the Chinese vocal art, promoted the development of Chinese vocal music, and broke the situation of music singing and art relying on the west, which laid the foundation for the establishment and development of Chinese vocal singing art.

\section{The Musical Style OF ChINESE ARt Songs IN THE MAY FOURTH PERIOD}

In the May Fourth Period, the new culture movement began to rise, and the Chinese culture began to change from the old thought to the new thought. This period of art songs express people's pursuit of scientific and democratic thought, with the spirit of the times, the art of song lyrics reflect the people of anti-imperialist and anti-feudal spirit, showing the musician concerns for the fate of the country reflects the compassion to the people.

\section{A. Taking the Realism as the Leading Thought}

The May Fourth Period is the period when Chinese culture is transformed from old culture to new culture. The main guiding ideology of artistic songs is realism, and musicians choose themes from real life. Under the background of the great era, the May fourth era of art songs fully develop the spirit of realism, and run realism into the works of art songs. The music works created are realistic. Under the guidance of this idea, the musicians in the May
Fourth Period have created a large number of excellent art songs. These are full of emotional expression of art songs, a distinct political tendency of the author, his works of art songs and the era of political struggle closely, the pursuit of scientific and democratic spirit, show political salvation and the author's aesthetic taste, creating a new situation in China modern music.

\section{B. The Pursuit of the Nationality of Artistic Creation}

The pursuit of ethnicity in the creation of art songs is a requirement for the vitality of artistic creation, and the musical style of Chinese art songs in the May Fourth Period adheres to this principle. In the May Fourth Period, the creation of art songs has made a great breakthrough compared with the previous ones. It didn't simply follow the tune of western music works, and gave more nationalization content when selecting themes. During this period, many musicians are returned from studying abroad, in a reasonable basis of Western classical and romantic music elements, combined with China's actual situation, in the context of the era, and actively seek suitable for China's national music, for this period of art song works marked a sharp national brand style.

\section{The Aesthetic Interest of the Social Value}

The musical style of Chinese art songs in the May Fourth Period also shows aesthetic interest in its social value. Most of the works produced by musicians during this period can reflect the real life at that time, showing the social value of music works and the aesthetic taste of authors in art songs. Realism is the guiding ideology of music creation, greatly shortens the aesthetic distance between the author and the public, and given the music connotation of nation, through the way of emotional expression China rich characteristics, displaying the national culture and spirit of the art songs of this period is more consistent with the aesthetic needs of the social civil cases.

\section{CONCLUSION}

The Chinese art songs in the May Fourth Period created a new situation of modern music in China.. In the May Fourth Period, the creation of art songs reflected the pursuit of progress of the masses in music style, laid the foundation for the establishment and development of Chinese singing art, and promoted the further development of Chinese art songs.

\section{REFERENCES}

[1] Lin Liu, Zhixin Wang. Mother river: Lin Liu. Zhixin Wang vocal music works selected [M]. Beijing: China Drama Press, 2002.

[2] Lili Wei. From the classification of Zhixin Wang's folk songs on the diversity of national vocal music [J]. Journal of Suzhou University, 2011.

[3] Xu Zhu. Solitude and fine cultivation alone -- a record of Zhixin Wang, director of the composer of the Central National Orchestra composer [J]. northern music, 2008.

[4] Min Chang. Call for the diversity of national vocal music works -from the Zhixin Wang phenomenon - talking about the [J]. people's music, 2010. 